\title{
Formation of need for human resources in implementation of high-speed and superhigh-speed railway projects
}

\author{
Oksana Rusakova \\ Department of Finance and Accounting \\ Irkutsk State Transport University \\ Irkutsk, Russian Federation \\ rusakova.OI@yandex.ru
}

\author{
Vladimir Bylkov \\ Department of Labour Economics \\ Baikal State University \\ Irkutsk, Russian Federation \\ bylkovvg@yandex.ru
}

\begin{abstract}
The article outlines the main prospects for the implementation of the strategic program for the construction and operation of high-speed traffic in the Russian Railways holding company. It was revealed that the introduction of new technological schemes of HS and SHS implies the provision of high-quality human resources. An analysis of the current demand for labor in the most important professional groups of employees of the JSC "Russian Railways" was conducted. It is proved that the current need allows only replacement of retiring human resources. The identification of methodological approaches to assess the long-term need for human resources is relevant. Estimated parameters of the demand for labor in the JSC "Russian Railways" are proposed with the implementation of high-speed traffic projects. The assessment of the capacity of the holding's professional training system for the needs of $\mathrm{HS}$ and SHS is presented.
\end{abstract}

Keywords - human resources, the need for manpower, the competence of workers, the level of mastering competences, vocational training, personnel training.

\section{INTRODUCTION}

The implementation of projects on the organization of high-speed traffic and superhigh-speed traffic within the framework of the JSC "Russian Railways" is one of the priority, innovative stages in the development of the railway transport of the Russian Federation. Experience in the design, construction and operation of high-speed and high-speed highways (here and after HS and SHS) in Europe and Asia, primarily China, shows that the implementation of such projects creates the basis for a dynamic economic growth of the country and increases its stability, along with further increase in efficiency. In addition, the expansion of the scale of high-speed traffic represents the basis for the development of related industries, many areas of small and medium-sized businesses, the economic recovery of cities and regions adjacent to high-speed railways. In the process of implementing the development strategy of the JSC "Russian Railways" until 2030, in 2015, the program for the organization of high-speed and high-speed railway communication in the Russian Federation (hereinafter referred to as the program) was updated and approved, based on state program documents, including "Forecast of the long-term socio-economic development of the Russian Federation for the period until 2030", "Transport strategy of the Russian Federation for the period until 2030". [1]

A strategy for the development of rail transport for the period up to 2030 assumes that the program provides for the implementation of $20 \mathrm{HS}$ and SHS projects, which will allow for the organization of more than 50 high-speed routes that will carry out at least 84 million trips per year, while the total length of lines with speeds of more than $160 \mathrm{~km} / \mathrm{h}$ will be more than 11 thousand $\mathrm{km}$.

One of the most important goals of the program is to accelerate the rate of economic growth and improve the quality of life of the population of Russia by creating a network of high-speed and superhigh-speed rail services that ensures the optimal ratio of speed and safety, comfort and fare for passengers. At the first stage of the implementation, the construction of the Moscow-Kazan SHS is envisaged, which is the most efficient project, and by the decision of the Government of the Russian Federation, JSC Russian Railways launched its implementation in 2015. [2]

One of the priority areas for the implementation of highspeed traffic projects is the formation of new highperformance, highly efficient, based on the use of information computer and digital technologies, workplaces. Therefore, in the process of introducing HS and SHS, it becomes necessary to assess the possibility of the JSC "Russian Railways" in the formation and attraction of highly intelligent human resources. The development of human resources in the industry assumes the provision of railway transport (at all levels) by professionally trained workers of mass professions, specialists and managers, oriented to long-term labor relations and building a professional career in rail transport; training of specialists of a wide profile and development of a high level of competence of railway transport personnel for work in the conditions of a unified transport system, active interaction of all modes of transport, logistics complexes and unified technological chains, high quality standards; assistance in the creation of corporate personnel management systems, focused on motivated and efficient work of employees, improving its quality, productivity, active participation in technical modernization and innovative development of rail transport. 
To implement these measures, tasks of a methodical and applied nature were posed. Firstly, you need to develop a method of predicting the railway transport personnel needs with the level of required education, category and specialization, providing planning and training, adapted to the implementation of long-term tasks of railway transport, in particular - the field of infrastructure and high-speed movement and other areas that provide innovative development.

Secondly, it is provided to ensure the elaboration and implementation of mechanisms for long-term cooperation between the Ministry of Transport of Russia, the Federal Service for Transport Supervision, Federal Railway Transport Agency, the companies of railway transport and educational institutions in the field of training and retraining of personnel (to expand the scope of the state order, targeted agreements in the format of public-private partnership, including using new financial - credit schemes), as well as in the field of science (to provide technical and technological modernization, the subsequent innovative development of rail transport at the expense of the development of fundamental and applied research, primarily on the basis of university complexes by strengthening their social, material - technical and scientificlaboratory base, creation of scientific-industrial, innovative and innovative centers, techno parks, transfer to them of the newest samples equipment, technology and software). The proposed directions should be based on some methodological approaches including the current and predict the long-term need for human resources.

\section{RESULTS}

Priority infrastructure projects on railway transport until 2030. high-speed lines (SHS) from Moscow to Tula, Kazan through Nizhniy Novgorod, from Ekaterinburg to Chelyabinsk should become highways. It is also proposed to accelerate the movement (HS) on the directions of Tula - Belgorod, Ekaterinburg - Nizhny Tagil, Novosibirsk - Barnaul. On the basis of the goals and tasks put forward, a set of works on the development of project documentation, engineering surveys, preparation of planning documents for the territory in accordance with the network plan for the implementation of the project for the construction of the Moscow-Kazan bridge, approved by the order of the Government of the Russian Federation of January 13, 2016, is being formed. [3]

The real socio-economic effect of the introduction of HS and SHS is due to the fact that additional factors appear that do not directly determine the economic benefit for the JSC "Russian Railways" and the state, but play an important socioeconomic role. Among them can be identified such as: first, the increase in the transport availability of different regions of the country in terms of urbanization. Secondly, the creation of conditions for efficiency with a real increase in the labor mobility of the population between the regions of the country. Thirdly, strengthening the social and territorial integrity of the Russian Federation, increasing the competitiveness of the transport network in the global transport services market. Fourthly, the increase in migration flows from the surplus regions to the regions of construction and operation of new railways, the increase in the culture and education of residents of areas that gravitate toward new railways, by expanding the possibilities for communication. Fifth, the increase in investment opportunities not only in the expansion of transport construction and the construction of transport infrastructure, but, most importantly, - increasing the opportunities for creating new jobs and employment in this sector of the economy. Sixth, improving the quality of human resources in the industry should be accompanied by the creation of a powerful system of professional training and retraining of the workforce, taking into account the introduction of $\mathrm{HS}$ and SHS.

Therefore, we can consider that one of the most important functions of the project to create and operate HS and SHS is the creation of new jobs, the development of new innovative areas of vocational training, the further expansion of opportunities for upgrading the skills of workers in high-tech areas of rail transport. As a promising direction, it is necessary to determine the capacity not only available, but also to identify the long-term need for human resources for the implementation of HS and SHS projects.

\section{DISCUSSION}

Meanwhile, such large-scale changes in the technological and scientific-technical direction are not linked to the plans for attracting and training the human potential of the industry. Thus, a one-time survey of the average number of organizations by types of activity conducted by Rosstat on October 31, 2016. [4] shows that the number of people employed in rail transport is 573984 people. With only $1.7 \%$ more than in a similar study in 2014. The data show that only slightly more than a third of the number of people employed in rail transport is classified as "skilled workers" (31.55\%), slightly less than a quarter (24.94\%) - "operators of production plants and machines, assemblers and drivers" 9.8\% - are specialists of the highest level of qualification, the remaining categories of employees account for less than 9\% of the population. (Table 1). An assessment of the current need for manpower implies ensuring the normal functioning of the railway transport in order to meet only the replacement demand. [5] In turn, additional labor requirements are either determined in an operational manner or are not taken into account at all. Prospective forecasting and planning of labor requirements at the level of the the JSC "Russian Railways" are not carried out. The prospective calculations carried out by the authors (Table 1) revealed structural changes in professional groups, taking into account the design work at the first stage of design and construction of the HSH (2017-2018). 
TABLE I. THE NUMBER OF EMPLOYEES OF ORGANIZATIONS BY PROFESSIONAL GROUPS AND TYPES OF ECONOMIC ACTIVITY AS OF OCTOBER 31,2016

\begin{tabular}{|c|c|c|c|c|}
\hline & $\begin{array}{l}\text { Total for the } \\
\text { activities }\end{array}$ & $\begin{array}{l}\text { Activities } \\
\text { of rail } \\
\text { transport }\end{array}$ & $\begin{array}{l}\text { Share } \\
\text { in } \%\end{array}$ & $\begin{array}{l}\text { Promising } \\
\text { calculations } \\
\text { for railway } \\
\text { transport }\end{array}$ \\
\hline $\begin{array}{l}\text { Total, } \\
\text { including: }\end{array}$ & 27837803 & 573984 & 100 & 100 \\
\hline Management & 2517820 & 39307 & 6,85 & 6,5 \\
\hline $\begin{array}{l}\text { Specialists of } \\
\text { the highest } \\
\text { qualification } \\
\text { level }\end{array}$ & 7300525 & 56230 & 9,8 & 10,9 \\
\hline $\begin{array}{l}\text { Specialists of } \\
\text { intermediate } \\
\text { skill level }\end{array}$ & 3071644 & 43358 & 7,56 & 8,3 \\
\hline $\begin{array}{l}\text { Employees } \\
\text { engaged in } \\
\text { preparation } \\
\text { and execution } \\
\text { of documents, } \\
\text { accounting and } \\
\text { maintenance }\end{array}$ & 1277605 & 50789 & 8,85 & 8,15 \\
\hline $\begin{array}{l}\text { Employees of } \\
\text { the service and } \\
\text { trade, } \\
\text { protection of } \\
\text { citizens and } \\
\text { property }\end{array}$ & 2520454 & 38608 & 6,75 & 5,35 \\
\hline $\begin{array}{l}\text { Qualified } \\
\text { workers of } \\
\text { industry, } \\
\text { construction, } \\
\text { transport and } \\
\text { workers of } \\
\text { related } \\
\text { occupations }\end{array}$ & 180953 & 180953 & 31,55 & 32,8 \\
\hline $\begin{array}{l}\text { Operators of } \\
\text { production } \\
\text { plants and } \\
\text { machines, } \\
\text { assemblers and } \\
\text { drivers }\end{array}$ & 3539261 & 143207 & 24,94 & 25,5 \\
\hline $\begin{array}{l}\text { Unskilled } \\
\text { workers }\end{array}$ & 3199999 & 21451 & 3,7 & 2,5 \\
\hline
\end{tabular}

The conducted sample survey showed that at the railway transport level the need to replenish human resources is regulated at a rate of only 8131 people. (Table 2). On the one hand, these criteria can be real, since it is $1.4 \%$ of the average number of people that can form the demand for labor replacement, as they focus on stable parameters of labor mobility.

TABLE II. THE NEED OF ORGANIZATIONS IN WORKERS TO FILL VACANT JOBS BY PROFESSIONAL GROUPS AND ECONOMIC ACTIVITIES AS OF OCTOBER 31,2016 [4]

\begin{tabular}{|c|c|c|}
\hline & $\begin{array}{l}\text { The need for } \\
\text { workers to fill } \\
\text { vacant jobs }\end{array}$ & $\begin{array}{l}\text { Share in total demand } \\
\text { (in \%) }\end{array}$ \\
\hline Total, including: & 8131 & 100 \\
\hline Management & 274 & 3,4 \\
\hline $\begin{array}{l}\text { Specialists of the highest } \\
\text { qualification level }\end{array}$ & 483 & 5,9 \\
\hline $\begin{array}{l}\text { Specialists of intermediate } \\
\text { skill level }\end{array}$ & 539 & 6,6 \\
\hline $\begin{array}{l}\text { Employees engaged in } \\
\text { preparation and execution of } \\
\text { documents, accounting and } \\
\text { maintenance }\end{array}$ & 364 & 4,5 \\
\hline $\begin{array}{l}\text { Employees of the service } \\
\text { and trade, protection of } \\
\text { citizens and property }\end{array}$ & 1311 & 16,1 \\
\hline $\begin{array}{l}\text { Qualified workers of } \\
\text { industry, construction, } \\
\text { transport and workers of } \\
\text { related occupations }\end{array}$ & 2788 & 34,3 \\
\hline $\begin{array}{l}\text { Operators of production } \\
\text { plants and machines, } \\
\text { assemblers and drivers }\end{array}$ & 1971 & 24,2 \\
\hline Unskilled workers & 401 & 4,9 \\
\hline
\end{tabular}

These criteria are in full agreement with the rather low level of staff turnover in the industry (at the level of 2.5-3.4\% in 2017). On the other hand, the intensification and dynamism of the introduction of HS and SHS indicates that the long-term need for labor is completely different. In addition, the structure of the need for human resources has completely different characteristics, in connection with the introduction of new technological principles. Due to the fact that rail transport belongs to the innovative spheres of the economy, so the multiplicative effect of creating jobs is most pronounced. The special importance of the quality of human resources is characteristic for the organization of HS and SHS, since their operation is associated with a high-tech process. However, the 
data provided by Rosstat show that only the current need for human resources is determined at the industry level.

The lack of accounting to the new jobs creation as a result of introduction and operation of HS and SHS in the Russian Federation leads to the fact that there are no approaches to predicting the future demand for human resources in the industry. All this leads to unreasonable variants of the forecasts of attracting and training workers who must occupy vacant jobs in the prospective sector of rail transport. To implement the structural adjustment, the country will require competent and highly qualified specialists, workers, employees and managers as the basis for the formation of a new technological order. According to S.Y.Glazyev, the emergence of a new technological order requires the mastering of new management technologies, outstripping the mastery of which and the training of personnel of the appropriate qualification are also a priority of development policy [6].

When assessing and forecasting the necessary human resources for the JSC "Russian Railways" we need to consider the totality of social and economic factors. First, the increase in passenger traffic and the volume of cargo transportation, invariably increase the need for human resources.

Research and international experience, comparison of the prospective passenger traffic in the organization of high-speed and high-speed traffic shows that when building a specialized high-speed railway with a maximum speed of up to $400 \mathrm{~km} /$ $\mathrm{h}$, passenger traffic can increase by 2 times due to a sharp increase in the competitiveness of rail transport and the corresponding attraction of passenger traffic from alternative modes of transport. Indeed, as defined by RBC, the JSC "Russian Railways" in 2017 year, received stable results for the development of passenger traffic. In 2017 year it was noted that the sending of passengers by high-speed trains increased by $35 \%$ and about 12.5 million people were transported. It was noted that in mid-2017. was sent 25millionth passenger train "Sapsan". In addition, the departure of passengers by trains "Swallow" increased by $25 \%$ and the departure of "Allegro" by train increased by $25 \%$.

Secondly, the construction and operation of HSH increases the human resources not only of operating personnel, but of workers in related industries. In addition, in the future it is noted that the Moscow-Kazan section can become part of the Moscow-Beijing high-speed highway, the construction cost of which is estimated at 7 trillion rubles, and the Silk Road project, which will link China to European markets and The Middle East. "Russian Railways" is positioning the project to build a $770 \mathrm{~km}$ high-speed Moscow-Kazan highway as a "pilot stage" in the formation of the Eurasia Eurasian Freight Line, a cargo and passenger line that will connect China's high-speed lines with the European Euro Carex. The experience of number of countries that implement HS and SHS and are oriented towards creating jobs can be applied to the possibility of creating jobs in such highly productive industries as rail transport. Based on the methodological approaches of Chinese scientists who evaluate the labor potential of high-speed railways, the forecasted options for the needs of the Russian Railways holding in employees replacing new jobs were determined. (Table 3 )
TABLE III. PROJECT OPPORTUNITIES FOR CREATING JOBS AND ATTRACTING HUMAN RESOURCES IN VARIOUS SECTORS WHEN DESIGNING THE COMMISSIONING AND OPERATION OF HS AND SHS FOR THE PERIOD UP TO 2024. (STEPS 1 AND 2 OF THE STRATEGY IMPLEMENTATION).

\begin{tabular}{|c|c|c|c|c|}
\hline $\begin{array}{c}\text { Normative } \\
\text { parameters of } \\
\text { human } \\
\text { resources }\end{array}$ & $\begin{array}{l}\text { Project (2017) } \\
\text { indicators of } \\
\text { construction } \\
\text { and operation } \\
\text { of HS and SHS }\end{array}$ & $\begin{array}{l}\text { Increase in the } \\
\text { volume of } \\
\text { passenger and } \\
\text { freight traffic } \\
\text { through the } \\
\text { introduction of } \\
\text { HS and SHS }\end{array}$ & \multicolumn{2}{|c|}{$\begin{array}{l}\text { Employment } \\
\text { development in } \\
\text { related sectors } \\
\text { for the } \\
\text { construction } \\
\text { and operation of } \\
\text { HS and SHS }\end{array}$} \\
\hline $\begin{array}{l}\text { Workplaces in } \\
\text { the main } \\
\text { (operational) } \\
\text { sector }\end{array}$ & 272732 & 8458 & 62637 & 6738 \\
\hline $\begin{array}{l}\text { Workplaces in } \\
\text { the design and } \\
\text { construction } \\
\text { sectors }\end{array}$ & 28890 & 1284 & 2268 & 1284 \\
\hline $\begin{array}{l}\text { Workplaces } \\
\text { providing } \\
\text { infrastructure } \\
\text { development }\end{array}$ & 11378 & 1462 & 2460 & 1580 \\
\hline Total & 273000 & 11204 & 67365 & 9602 \\
\hline
\end{tabular}

Objective prerequisites for increasing the demand for hightech and highly intelligent personnel require a forward-looking assessment and planning of the capacity of the necessary human resources.

\section{CONCLUSION}

Ultimately, as a result of calculations, it was determined that during the implementation of the first and second phase of the HS and SHS project implementation, the country will need an additional 361171 high-performance and high-tech jobs with the involvement of intellectual highly skilled human resources. This means that, on average, 60000 new jobs can appear annually in this sector of the economy, related not only to construction and the operation of HS and SHS, but also to the functioning of the infrastructure of this high-tech sphere.

On the other hand, an equally important problem of attracting personnel is the identification of the capabilities of the system of vocational training, retraining and upgrading of human resources oriented to the implementation of high-speed traffic projects. The Personnel Management Department of the JSC "Russian Railways" identified the most important areas in the training of personnel [7]. The main elements and vocational groups and training centers have been identified. As it is established in 2015, the contingent of the university complex of railway transport is 40473 students - full-time and part-time students, who study under the programs of higher education and programs of ACT. Data show that the volume of training in the training centers of the JSC "Russian Railways" qualification in 2015 made up 29200 people according to the newly trained workforce, 23600 passed training and retraining in the second professions. The total scale of the training of working cadres was 52.8 thousand people. In these training centers, 154000 people have 
improved their qualifications. In the branch training centers, more than 55.2 thousand people have improved their qualifications, 42,1 thousand people have been trained, more than 14,3 thousand people have passed retraining and training to the second professions.

For various targeted and specialized programs in various fields, more than 16000 managers were trained at the Corporate University of the Russian Railways holding company. On the one hand, the capacity of training centers within the framework of the the JSC "Russian Railways" is quite enough to ensure the formation of high-quality human resources of the industry. On the other hand, the system of professional training does not take in consideration the peculiarities of construction and operation of high-speed traffic, including the mastering of the competence of information and communication technologies (ICT) competencies.

The following is recommended in the period of preparation and implementation of the subsequent stages of the Strategy for the implementation of HS and SHS in railway transport in 2018-2024:

- Creation of a high-tech specialized training module for personnel training, taking into consideration the introduction of advanced HS and SHS technologies in educational institutions of higher education and secondary vocational programs.

- Allocation of separate departments and groups in the training centers of the JSC "Russian Railways" qualification of promising professional areas related to the HS and SHS, including ICT.

- Holding in a separate direction and carry out training on specialized programs for the intellectualization of production for managers in the Corporate University.
- Updating the competencies of employees focused on the development, implementation of HS and SHS.

- Strengthening the competence in the system of unified corporate requirements (UCR) of the holding "RZD", characteristic for HS and SHS.

- Forming the system of professional retraining and advanced training of employees of the holding, focused on HS and SHS on transport.

\section{References}

[1] Transport strategy of the Russian Federation for the period up to 2030. Access mode: http://www.consultant.ru/law/hotdocs/50825.html/

[2] Order of the Government of the Russian Federation "on Amendments to the Transport Strategy of the Russian Federation". 1032-p (electronic document) // Access mode: http: // www. consultant.ru/law/hotdocs/34693.html/ (circulation date.)

[3] Order of the Government of the Russian Federation of 13.01.2016. № 5p. (together with the "Network plan for the implementation of the project for the construction of the high-speed railroad Moscow-Kazan"). Access mode:

https://government.consultant.ru/documents/3707335? items=1\&page=1

[4] On the number and needs of organizations in workers by professional groups as of October 31,2016 , based on the results of a sample survey of organizations. Access mode: http://www.gks.ru/free_doc/2017/potrorg/potr16.htm

[5] Bylkov V.G. Regular transformations of demand in the labor market / V.G. Bylkov // Izvestia IGEA-2015.-№3.- P.416-425.

[6] Glazyev S.Y. On the policy of advanced development in conditions of changing technological structures // Sustainable innovative development: design and management: electron. sci. ed. 2013. № 2. P. 15-28. Access mode: www.rypravlenie.ru.

[7] The report of deputy. Head of the Department of Personnel Management Chirva IP "On new aspects in personnel training for the branches of JSCo Russian Railways. Access mode: http://www.rzdexpo.ru/innovation/scientific_and_technical_co_operation_in_innovatio n/vzaimodeystvie-s-obrazovatelnymi-organizatsiyami-vysshegoobrazovaniya/prezentatsii/6.pdf 